Nadwa : Jurnal Pendidikan Islam

Vol. 12, Nomor 1 Tahun 2018

Accredited by Ristekdikti based on Decree No. 51/E/KPT/2017

\title{
Model Perkuliahan Pendidikan Agama Islam Yang Damai, Moderat, dan Toleran
}

\author{
Munawar Rahmat \\ Universitas Pendidikan Indonesia, Bandung \\ munawarrahmat.pai@upi.edu
}

\begin{abstract}
The study aims to describe the model of Islamic Religious Education (PAI) lectures that are peaceful, moderate, and tolerant in Indonesia University of Education (UPI). The research method used is descriptive-qualitative. The study found that the peaceful, moderate, and tolerant model of Islamic Education is to use open-ended lecture models that include the openness of lecturers, materials and methods. The openness of the lecturer is shown by the attitude and the thinking of the lecturer who sees the difference of understand, madzhab and religion as necessity and not exclusive, material disclosure is shown by substantive and inclusive material selection, while method openness is demonstrated by the use of an argumentative dialogical learning method consisting of ushul study cross-mazhab method, methodology of madhahab typhology and method of study of religions.
\end{abstract}

Keywords: Islamic Education; moderate; tolerant; openness of lecturers

\begin{abstract}
Abstrak
Penelitian bertujuan mendeskripsikan model perkuliahan PAI yang damai, moderat, dan toleransi di Universitas Pendidikan Indonesia (UPI) Bandung. Metode penelitian yang digunakan deskriptif-kualitatif. Penelitian menemukan bahwa Model Pendidikan Agama Islam yang damai, moderat, dan toleran yaitu menggunakan model perkuliahan yang terbuka yang meliputi keterbukaan dosen, materi dan metode. Keterbukaan dosen ditunjukkan dengan sikap dan pemikiran dosen yang melihat perbedaan paham, mazhab dan agama sebagai keniscayaan dan tidak bersifat eksklusif; keterbukaan materi ditunjukkan dengan pemilihan materi secara substantive dan inklusif,sedangkan keterbukaan metode ditunjukkan dengan penggunaan metode pembelajaran yang dialogis argumentatif yang terdiri dari metode studi ushul lintas mazhab, metode tipologi mazhab dan metode studi agama-agama.
\end{abstract}

Kata kunci: Pendidikan Agama Islam; damai; moderat; toleran; metode dialog argumentatif 


\section{Pendahuluan}

Masalah kerukunan hidup beragama di Indonesia masih menjumpai berbagai persoalan. Konstitusi Negara menjamin kebebasan beragama bagi setiap warga negara. Para tokoh bangsa dan pemuka agama sering menyampaikan perlunya warga negara untuk menjalankan agama sesuai dengan keyakinannya masingmasing serta menghargai agama dan penganut agama berbeda. Tapi realitasnya sikap intoleran dan disharmoni justru menghiasi masalah sosial-keagamaan di Indonesia. Masalah intoleransi di kalangan internal muslim beda mazhab masih sangat tinggi. Penganut mazhab berbeda, terutama mazhab minoritas, dicap sesat dan kafir. Di masa-masa awal bentuk penolakan ini hanya dilakukan lewat tulisan-tulisan dan pengajian terbatas.

Ahmadiyah dilarang di Indonesia, tapi ajaran ini tetap berkembang. Ajaran ini diusik kembali tahun 2006, puncakpuncaknya tahun 2010-2011. Rumah-rumah warga Ahmadiyah di Cikeusik Pandeglang dibakar massa.1 Beberapa tahun kemudian masjid-masjid dan lembaga-lembaga pendidikan Ahmadiyah ditutup paksa. Bahkan penganut tarekat yang lebih mengedepankan dimensi batin ternyata diusik pula. Kampung warga tarekat Tijaniyah di wilayah selatan Sukabumi dibakar massa.2

Mengenai madzhab Syiah, Majelis Ulama Indonesia (MUI) dan Pemerintah (pusat) tidak pernah melarang warga dan ajaran Syi ah. Muhyiddin Junaidi, Ketua MUI bidang Hubungan Luar Negeri, menyatakan bahwa MUI tidak pernah melarang ajaran Syi ah di Indonesia. Tahun 2004 MUI hanya mengeluarkan surat himbauan agar umat Islam meningkatkan kewaspadaan tentang kemungkinan beredarnya kelompok Syi’ah yang ekstrim.3 Tapi

1 Tempo.co., Kronologi Penyerangan Jamaah Ahmadiyah di Cikeusik. (http://www.m.tempo.co.) (online) diakses 6 Februari 2011.

2 Eramuslim.com, Aliran Sesat Pemicu Konflik di Sukabumi? (http://www.eramuslim.com.) (online) diakses 23 Agustus 2012.

3 Bbc.com., Ajaran Syiah, ... diakses 15 Oktober 2015. 
MUI daerah ada yang menyesatkan Syi ah, antara lain MUI Jawa Timur dan Sulawesi Selatan. NU dan Muhammadiyah, sebagai dua organisasi terbesar di Indonesia, menolak fatwa MUI daerah tersebut. Sekretaris Muhammadiyah Abdul Muthi menolak adanya fatwa sesat terhadap Syi ah dari lembaga keagamaan mana pun. Fatwa sesat dari MUI di sejumlah daerah, seperti Jawa Timur dan Sulawesi Selatan, terbukti menjadi alat melegitimasikan kekerasan terhadap pengikut Syi`ah dan memicu konflik horizontal antar umat Islam. "Fatwa dari mana pun harus tidak untuk mengkafirkan dan menyesatkan." Sikap serupa muncul dari Rois Syuriah NU DIY, KH Asyhari Abta. Dia menyatakan MUI DIY tidak perlu menggubris permintaan Front Jihad Islam. Kyai dari Pesantren Krapyak Yogyakarta ini menganggap fatwa sesat malah bisa memicu konflik antar kelompok berbeda paham agama. "Bisa memperuncing perbedaan dan memicu tabrakan antar kelompok," ujar dia.4

Prof. Dr. Din Syamsuddin, mantan Ketua Umum PP Muhammadiyah, mengatakan bahwa baik Sunni maupun Syi ah adalah sama-sama Muslim karena masih berada di lingkaran syahadat. Menurutnya, yang mempercayai syahadat itu otomatis Islam, apa pun mazhabnya. Syi`ah maupun Sunni pasti mempunyai keunggulan dan kekurangan masing-masing. Kedua hal itu, harus disikapi dengan mengedepankan rasa saling menghargai dan toleransi satu sama lain..5 Ketua Umum PBNU Said Aqil Siraj mengatakan ajaran Syi ah tidak sesat dan termasuk Islam seperti halnya Sunni. "Di universitas Islam mana pun tidak ada yang mengangap Syi' ah sesat”. Said merujuk pada kurikulum pendidikan pada almamaternya Universitas Umm AlQuro di Arab Saudi yang dikenal sebagai pusat Wahabi yang keras. "Wahabi yang keras saja menggolongkan Syi`ah bukan

4 Tempo.co., Muhammadiyah dan NU Tolak MUI Fatwakan Sesat Syi ah, (https://www.nasional.tempo.co.) (online) diakses 20 Desember 2013

5 Fokustoday.com., Muhammadiyah: Tidak ada fatwa sesat buat Syi'ah, (https://www.fokustoday.com.) (online) diakses 13 Oktober /2017. 
sesat," ujarnya.6 Tapi memang ada sejumlah ulama NU dan Muhammadiyah yang menyesatkan Syi ah, sehingga sikap masyarakat terhadap Islam Syi ah pun terbelah tiga: menerima kehadiran Syi ah, menyesatkan, dan netral.

Hasil-hasil penelitian terdahulu menunjukkan bahwa sikap eksklusif dan radikalisme beragama akhir-akhir ini merambah dengan cepat kepada masyarakat luas. Syafi i menemukan, gerakan radikalisme agama merambah kepada masyarakat dengan begitu cepat. Penyebabnya media-media kanan yang banyak bermunculan di masyarakat yang sering kali menghembuskan berita-berita sinis terhadap ajaran di luar kelompoknya. Para muballigh pun sering kali mengkhutbahkan agama dalam bentuk kutukan, penyesatan, dan penghinaan terhadap kelompok-kelompok non mainstream. Adapun gejala radikalisme agama ditandai oleh beberapa hal: (1) kecenderungan untuk menafsirkan teks (al-Quran dan hadits) secara tekstual dan mengabaikan konteks; (2) adanya orientasi pada penegakan syari ah; dan (3) adanya kecenderungan anti pluralisme.7

Hasil penelitian yang sama ditemukan oleh Mujani, menurutnya paling tidak ada satu dari 10 orang Indonesia yang menyetujui aksi-aksi kekerasan dan terorisme.8 Thalib menemukan juga bahwa masyarakat muslim Indonesia masih memandang rendah agama dan mazhab yang berbeda.9 Hasil penelitian Rahmat 2006 menunjukkan, bahwa lebih separoh mahasiswa UPI (Bandung) memiliki corak berpikir keagamaan

6 Tempo.co., Said Aqil: Syiah Tidak Sesat. (https://www.nasional.tempo.co.) (online) diakses 27 Januari 2012.

7 Syafi i, Radikalisme Beragama, (http://www..islamlib.com.) (online) diakses 20 Maret 2006.

8 Mujani, Kecenderungan Radikalisme Agama Akhir-akhir Ini, (http://www.islamlib.com.) (online) diakses 20 Maret 2006.

9 Thalib, al-Ustad Ja far Umar, Toleransi Beragama, (http://www.indonesiaindonesia.com.) (online) diakses 15 Oktober 2014. 
yang eksklusif.10 Kemudian pada tahun 2009 populasi penelitian diperluas di Jawa Barat. Ternyata hasilnya sama, bahwa lebih separoh mahasiswa di Jawa Barat memiliki corak berpikir keagamaan yang eksklusif.11

Perkuliahan PAI di perguruan tinggi memiliki fungsi selain memperkokoh keislaman mahasiswa, juga membangun keberagamaan yang damai, moderat, dan toleran. Penelitian ini bertujuan untuk memahami model perkuliahan PAI yang damai, moderat, dan toleran. Berdasarkan teori psikologi agama, manusia yang matang beragama adalah penganut agama yang damai, moderat, dan toleran. Gordon Alport merinci ciri-ciri orang yang matang beragama terutama taat beragama, damai, moderat, toleran, dan selalu terbuka untuk mencari kebenaran dari mana saja.12 Willian James, menyebutkan empat ciri orang yang matang beragama, yakni: sensibilitas akan eksistensi Tuhan, kesinambungan dengan Tuhan dan penyerahan diri pada-Nya, rasa bahagia dan kebebasan yang membahagiakan, dan mengalami perubahan dari emosi menjadi cinta dan harmoni.

Orang yang beragama matang mencapai perasaaan tenteram dan damai, di mana cinta mendasari seluruh hubungan interpersonalnya. Oleh karena itu, orang beragama matang bebas dari rasa benci, prejudice, permusuhan, dan lain-lain, tetapi cinta dan harmoni merupakan dasar bagi kehidupan sosial atau interpersonalnya. Tipe ideal manusia yang matang

10 Rahmat, M., "Corak Berpikir Keagamaan Mahasiswa (Eksklusif, Inklusif, dan Liberal)," Taklim - Jurnal Pendidikan Agama Islam, Vol. 10 No. 1 (Maret 2012): 13-37.

11 Syahidin \& Rahmat, M., 2009, Corak Berpikir Keagamaan Mahasiswa di Jawa Barat: Dari Corak Berpikir Keagamaan yang Eksklusif, Inklusif, hingga Liberal. Penelitian Kompetitif Dikti pada LPPM UPI Bandung.

12 Clark, W.H., 1968, The Psychology of Religion: An Introduction to Religious Experience and Behavior, The MacMillan Company, New York, hlm. 242-243. 
beragama menurut James adalah Rahib dan Bikkhu, 13 atau menurut Ismail adalah Sufi, dengan ciri-ciri taat beragama, damai, moderat, dan toleran. Adapun orang yang rajin beribadah tapi juga berbuat keburukan dan intoleran, maka keberagamaan orang semacam ini tidak matang.14

\section{Metode Penelitian}

Penelitian menggunakan deskriptif-kualitatif. Teknik penelitian menggunakan wawancara mendalam (depth interview), observasi partisipan, dan studi dokumentasi. Depth interview dilakukan secara langsung dan tidak langsung, observasi partisipan dilakukan ketika mengajar (terutama ketika team teaching) serta membimbing dan menguji mahasiswa. Kedua kegiatan penelitian lapangan ini dilakukan sepanjang tahun 2017. Adapun dokumen yang digunakan adalah tulisan-tulisan (artikel penelitian dan laporan penelitian) dan bahan kuliah paling mutakhir (tahun 2017).

Responden penelitian adalah tiga dosen PAI nominator paling produktif dan moderat tingkat nasional Kementerian Agama RI Tahun 2017. Dari sebanyak 10 nominator dosen PAI se Indonesia, tiga dosen berasal dari UPI. Sesuai urutan nominator, ketiga dosen UPI ini adalah Prof. Dr. Abas Asyafah, M.Pd., Prof. Dr. Endis Firdaus, MA, dan Dr. Munawar Rahmat, M.Pd.15 Responden pertama berlatar-belakang NU dan bercorak pikir religius inklusif. Responden kedua berlatar belakang Persis

13 James, W., 1958, The Varieties of Religious Experience: A Study in Human Nature, Modern Library, New York, hlm. 59.

14 Ismail, R., "Konsep Toleransi dalam Psikologi Agama (Tinjauan Kematangan Beragama)," Religi - Jurnal Studi Agama-Agama, Vol. 8 No. 1 (Januari 2012): 1-12.

15 Ditjen Pendidikan Islam Kemenag, Nominator Penerima Apresiasi Pendidikan Islam untuk Guru dan Dosen Pendidikan Agama Islam 2017, SK Ditjen Pendidikan Islam Kemenag RI No. 6921 Tahun 2017, 20 November 2017. 
dan bercorak pikir religius inklusif, bahkan cenderung liberal; dan responden ketiga berlatar-belakang Muhammadiyah dan bercorak pikir religius inklusif.

\section{Substansi materi PAI}

Substansi materi PAI yang dipilih ketiga dosen ada yang sama dan ada juga yang berbeda. Tapi tujuannya sama yakni membangun sikap dan perilaku Islam yang damai, moderat, dan toleran. Substansi materi yang sama dapat diringkas dalam tabel berikut.

Tabel 1: Substansi materi PAI yang damai, moderat, dan toleran

\begin{tabular}{|c|c|c|}
\hline No. & Tema & Uraian Substansi Materi \\
\hline & $\begin{array}{l}\text { Makna } \\
\text { beragama Islam } \\
\text { adalah tunduk- } \\
\text { patuh secara } \\
\text { mutlak kepada } \\
\text { Allah dan Rasul- } \\
\text { Nya }\end{array}$ & $\begin{array}{l}\text { Agama (al-din) adalah al-khudhu al- } \\
\text { muthlaq, yakni tunduk-patuh secara mutlak } \\
\text { (kepada Allah); sedangkan kata Islam berasal } \\
\text { dari tiga akar kata: aslama (berserah diri atau } \\
\text { tunduk-patuh), salamaatau salima (tentram, } \\
\text { damai), dan salamatan (selamat). Dengan } \\
\text { melihat akar katanya, kata Islam mengandung } \\
\text { makna-makna berikut: }\end{array}$ \\
\hline & & $\begin{array}{l}\text { Aslama (tunduk patuh, pasrah, berserah } \\
\text { diri). Maksudnya, berserah diri dengan } \\
\text { tunduk-patuh kepada Allah dan Rasul- } \\
\text { Nya, hanya menyembah Allah semata, } \\
\text { dan tidak menyembah sembahan yang } \\
\text { lain selain Allah. } \\
\text { b. Salama atau salima (tentram, damai). } \\
\text { Maksudnya, orang-orang yang memilih } \\
\text { Islam sebagai agamanya maka rasa } \\
\text { hatinya akan tentram/damai. Berdasarkan } \\
\text { firman-Nya dalam al-Quran, orang-orang } \\
\text { beriman hatinya akan tentram/damai } \\
\text { karena rasa hatinya selalu: (1) mengingat } \\
\text { Allah (selalu berzikir), dan (2) } \\
\text { bertawakkal (menyerahkan/mewakilkan } \\
\text { urusannya) kepada Allah. Selain itu } \\
\text { mengandung makna pula bahwa Islam } \\
\text { menjungjung tinggi pola hidup yang }\end{array}$ \\
\hline
\end{tabular}


damai dan harmoni.

c. Salamatan (selamat). Maksudnya, orang-orang yang memilih Islam sebagai agamanya maka mereka akan memilih kebahagiaan hidup dunia-akhirat dan menghindari bencana abadi (nerakaNya). Kunci memilih kebahagiaan hidup dunia-akhirat dan terhindar dari api neraka adalah memilih kematian yang selamat (mati husnul khatimah), karena "mati" - yang hanya satu kali terjadi merupakan pintu gerbang akhirat. Makna memilih Islam di sini bukan sekedar beragama Islam secara formal melainkan memilih Islam secara substantif. Buktinya, Nabi saw. mengadakan shalat jenazah bagi Gubernur Mesir, padahal dia seorang Kristen.

2. Misi (tujuan utama) agama Islam adalah 'menyempurna kan' akhlak mulia.
Dalam sebuah hadits Nabi Muhammad saw. bersabda:

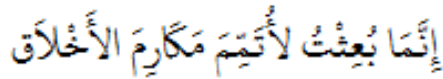 \\ Sesungguhnya aku (Nabi/Rasul) diutus 'menyempurnakan'akhlak yang mulia.16}

Misi kenabian untuk menyempurnakan akh. Sayang Allah bagi manusia, agar akhlaknya m Allah sebagaimana diajarkan dan diteladankan mulia yang dipribadikan secara 'benar' dan dili mulia disebut benar jika akhlak mulia itu ( kepada Allah dan Rasul-Nya. Kemudian akhl; dilakukan secara ikhlas, yakni dengan niat semata); bukan karena pamrih dunia (seperti in yang berakhlak mulia), dan bukan pula $\mathrm{k}$ memperoleh pahala, ingin masuk surga, atau ta Para nabi dan rasul merupakan teladan-tel Muhammad saw. sebelum diangkat mes menampilkan akhlak mulia yang sempurna. Be (manusia yang paling dapat dipercaya). Tuhan 'berakhlak tinggi': Wa innaka la`allâ khuluqin

16 Wahab, 2015, Kumpulan Hadits Sesuai Abjad. E-Book (http://www.ahabiy.blogspot.com.), hadits No. 34. 
mempunyai akhlak yang tinggi (QS 68/al-Qalam ayat 4. Ke 33/al-Ahzab ayat 21 ditegaskan bahwa Rasulullah sebą Laqod kâna lakum fî rasûlillâhi uswatun hasanatun = prib merupakan suri teladan, yakni bagi orang yang berkehenda Allah, meyakini hari akhir, dan banyak berzikir.

Kita simak sejarah para nabi, mereka adalah manusia-mar merendahkan diri di hadapan Allah dan paling rendah hati di (tidak ada kesombongan sebesar biji sawi pun), dan manu paling banyak bertaubat; padahal mereka adalah manus ma shum (terbebas dari segala dosa dan salah) tapi dirin banyak melakukan dosa-dosa dan kesalahan. Sifat-sifat i diteladani oleh orang-orang beriman. Nabi Muhamr direndahkan, dicemooh, dihina, difitnah, diludahi, dilempa unta, bahkan dilempar dengan batu (saking bencinya $r$ nabi/rasul). Tapi beliau selalu mengalah, tidak pernah mer mereka. Beliau bahkan ber-istighfar dan memohon pe mendoakan orang-orang yang yang jahat itu. Ketika istir (seorang kaya-raya, yang dihormati masyarakat) dan pama (pemimpin Makkah yang sangat dihormati masyarak melindungi beliau meninggal dunia, Nabi saw. pergi ke Tha perlindungan kerabat-kerabatnya. Tapi bukannya dilindu dilempari dengan batu hingga salah satu giginya pecah. gunung tidak terima atas perlakuan penduduk Thaif. Ia $\mathrm{m}$ gunung dan meminta izin kepada Nabi untuk melemp mereka. Saking mulianya akhlak Nabi, beliau tidak men beliau berdoa: Allâhummahdi qaumî fainnahum lâ ya'la berilah hidayah kepada kaumku karena sesungguhnya merel yang tidak mengetahui.

3. Meneladani
kesempurnaan
keimanan,
ketakwaan,
peribadatan,
akhlak mulia,
dan ilmu
Rasulullah
(tentu semampu
masing-
masing).

Sesungguhnya telah ada pada (diri)
Rasulullah itu suri teladan yang baik bagimu, (yakni) bagi orang yang mengharap (karunia, rahmat, dan perjumpaan dengan) Allah dan (mengimani) hari akhir, dan dia banyak menyebut (mengingat) Allah. (QS 33/alAhzab ayat 21)

Syarat meneladani Rasul ada tiga: (1) mengharap (karunia, rahmat, pengampunan, dan perjumpaan dengan) Allah, (2) mengimani hari akhir, dan (2) banyak menyebut/mengingat Allah (banyak berzikir). 
Rasul adalah manusia sempurna (insan kamil), sehingga keimanannya sempurna, ketakwaannya sempurna, peribadatannya sempurna, akhlak mulianya sempurna, dan ilmunya sempurna. Kesempurnaankesempurnaan inilah yang perlu diteladani oleh orang-orang yang beriman.

4. Keragaman mazhab dan keyakinan religius dalam Islam sebuah keniscayaan. a. Ketika Nabi Muhammad masih berada di tengah-tengah umat, semua sahabat Nabi (kaum muslimin) hanya merujuk kepada beliau, sehingga pada saat itu hanya ada satu Islam tanpa mazhab.

b. Beberapa saat setelah Nabi saw. wafat muncul dua mazhab, yakni mazhab sahabat (cikal-bakal mazhab Sunni) dan mazhab Ahlul Bait Nabi (cikal-bakal mazhab Syi ah). Referensi Islam mazhab sahabat adalah al-Quran dan Sunnah Nabi yang terekam dalam kesaksian, hapalan, dan catatan para sahabat; sedangkan referensi Islam mazhab Ahlul Bait Nabi adalah para Imam yang datang secara silih berganti hingga Imam ke-12. Artinya, mazhab sahabat langsung berijtihad, sedangkan mazhab Ahlul Bait baru berijtihad setelah gaibnya Imam ke-12. Setelah itu Islam Sunni terbentuk ke dalam beberapa mazhab teologi ('Asy`ariyah, Maturidiyah, dan Mu`tazilah) dan hukum/fiqih (Hanafi, Maliki, Syafi i, dan Hambali). Islam Syìh pun menjadi beberapa mazhab, yang terbesar adalah Syi ah 12 Imam. Saat ini, selain Sunni dan Syi ah, pada abad XVIII-XIX masehi lahir Wahabi, dan abad XX lahir Ahmadiyah. Di Indonesia terbentuk semacam mazhab, yakni: NU (eklektif Sunni-Syi ah), Muhammadiyah (eklektif Sunni-Wahabi), dan Persatuan Islam (lebih dekat ke Wahabi).

c. Perbedaan mazhab sebenarnya sebuah keniscayaan, karena: (1) perbedaan 
pemahaman terhadap Al-Quran, misalnya adanya ayat-ayat yang muhkammutasyabih, tanzil-takwil, nasikhmansukh, serta 'am-khash; (2) perbedaan para ahli hadits di dalam menentukan kriteria keshahihan sebuah hadits; dan (3) perbedaan metode ijtihad.

d. Atas dasar itu, karena semua mazhab dalam Islam berbasis ijtihad, maka tidak boleh satu mazhab mengklain bahwa mazhabnyalah yang benar sedangkan mazhab lain sesat/kafir. Vonis sesat/kafir hanya otoritas Allah dan Rasul-Nya.

Substansi materi PAI lainnya dari responden kedua dan ketiga adalah tentang makna iman dan kafir dan makna ahli kitab. Makna iman dan kafir perspektif kedua responden sebagai berikut:

1. Iman bukan sekedar percaya melainkan ma`rifatun wa tashdiqun. Ma'rifatun artinya mengetahui atau mengenal. Maksudnya mengetahui atau mengenal Tuhan yang nama-Nya Allah. Tashdiqun artinya membenarkan. Maksudnya membenarkan bahwa orang yang mengenalkan Tuhan itu adalah Rasulullah. Karena itulah rukun Islam pertama adalah mengucapkan dua kalimat syahadat.

2. Iman merupakan dasar beragama dan sangat menentukan nasib kehidupan di hari kemudian. Jika ketika hidup di dunia memiliki keimanan, maka ketika menghadapi kematian (yang hanya satu kali terjadi) akan mengalami kematian dengan selamat (mati husnul khatimah). Dan sebaliknya, jika ketika hidup di dunia tidak memiliki keimanan maka ketika menghadapi kematian (yang hanya satu kali terjadi) akan mengalami kematian yang sesat (mati su`ul khatimah). Jadi, keimanan itu ibarat angka 1 (satu) di depan dan ketiadaan iman (kafir) ibarat angka 0 (nol) di depan, sedangkan peribadatan dan amal saleh ibarat angka 0 (nol) di belakang. Angka 0 di belakang angka 1 tentu sangat berharga. Misal 10 
dan 100, tambahan angka 0-nya sangat berharga. Tapi jika di depannya angka 0 , maka angka 0 di belakang angka 0 itu sama sekali tidak berharga. Angka 1 (satu) jauh lebih berharga dibandingkan angka 0.000.000.000.000 (walaupun jumlah angka 0 di belakangnya sepanjang jalan kereta api).

3. Kafir adalah kebalikan dari iman. Kafir artinya menolak keimanan. Jadi, orang kafir adalah orang yang hatinya menolak Allah dan Rasul-Nya. Dengan demikian orang yang tidak secara tegas menolak Allah dan Rasul-Nya tidak boleh dituduh sebagai orang kafir. Vonis iman dan kafir hanyalah milik Allah semata. Maksudnya, hanya Allah dan Rasul-Nya yang mengetahui keimanan dan kekafiran seseorang.

4. Bagaimanakah halnya dengan orang-orang yang tidak mengetahui Allah dan Rasul-nya dan tidak pula menolaknya? Ternyata Nabi Muhammad saw. menyebutnya sebagai orangorang Jahiliyah. Karena itulah Al-Quran tidak pernah memvonis kafir kepada orang-orang yang beragama Yahudi, Nasrani, Majusi, dan Shabi in. Abu Lahab divonis kafir karena dia dengan tegas-tegas menolak Rasul, bahkan terangterangan memusuhi dan memerangi Nabi saw. Demikian juga Abu Talib, walau ia berakhlak baik dan melindungi Nabi, tapi dia divonis kafir karena hatinya menolak kerasulan Nabi Muhammad saw. Adapun kepada orang-orang di luar Islam dan di luar kafir Nabi saw. menyebutnya Jahiliyah, Yahudi, Nasrani, Majusi, atau Shabi in. Jadi, kepada orang-orang yang beragama non muslim tidak boleh menyebut orang kafir. Terlebih-lebih lagi kepada orang-orang Islam yang berbeda mazhab sama sekali tidak boleh menyebut kafir. Vonis kafir kepada seseorang hanya hak prerogatif Allah swt. dan RasulNya.

Makna dan karakter ahli kitab yang dipresentasikan kedua responden di kelas kepada mahasiswa sebagai berikut:

1. Ahli Kitab merujuk kepada orang-orang yang beragama dengan mengikuti Rasul terdahulu, misalnya penganut agama 
Yahudi dan Nasrani. Karena itu mereka beragama dengan bersandar kepada Kitab Suci yang telah diturunkan kepada Rasul mereka (QS 5/al-Maidah ayat 15).

2. Di antara Ahli Kitab ada yang berkarakter baik, yakni rendah hati (tidak sombong) dan amanah (jujur). Tapi di antara mereka ada yang berkarakter buruk, yakni mengingkari ayatayat Allah, suka mencampur-adukkan yang hak dan yang batil, menyembunyikan kebenaran, dan khianat (QS 3/Ali Imran ayat 71, 75, 199, QS 4/al-Nisa ayat 123).

3. Di antara Ahli Kitab ada yang beriman kepada Allah, berlaku lurus, rendah hati (tidak sombong), membaca ayat-ayat Allah pada sebagian malam, dan bersujud (tunduk-patuh kepada Allah) (QS 3/Ali Imran ayat 113 dan 199). Tapi kebanyakan Ahli Kitab adalah kafir (QS 2/al-Baqarah ayat 105 dan 109, QS 3/Ali Imran ayat 70-71, dan QS 5/al-Maidah ayat 15).

Adapun kriteria Islam 'menyimpang' (karenanya perlu diluruskan, tapi jangan divonis kafir) yang dipresentasikan di kelas oleh responden pertama dan ketiga sebagai berikut:

1. Menghalalkan apa-apa yang jelas-jelas diharamkan (misal menghalalkan riba) dan mengharamkan apa-apa yang jelasjelas dihalalkan oleh Allah (misal mengharamkan jual-beli).

2. Mewajibkan apa-apa yang jelas-jelas tidak diwajibkan (misal mewajibkan shalat dhuha dan puasa senin-kamis) dan tidak mewajibkan kepada apa-apa yang jelas-jelas diwajibkan oleh Allah (misal tidak mewajibkan shalat 5 waktu, puasa ramadhan, membayar zakat, dan hajji ke baitullah).

3. Mencaci-maki tokoh dan umat beda agama dan beda mazhab secara terbuka, baik lisan maupun tulisan, bukan karena mengadakan pembelaan.

4. Membubarkan aktivitas keagamaan, pengajian, dan pendidikan agama kepada kelompok agama dan mazhab minoritas yang lemah. 
5. Menutup paksa, merusak, dan memusnahkan rumah-rumah ibadat dan rumah-rumah serta harta milik tokoh dan umat minoritas agama dan mazhab yang lemah.

\section{Metode Perkuliahan PAI}

Metode perkuliahan PAI yang diimplementasikan oleh ketiga responden berbeda-beda. Tapi tujuannya sama, yakni membangun sikap dan perilaku Islami yang damai, moderat, dan toleran. Ketiga macam metode yang dikembangkan oleh responden sebagai berikut.

Responden pertama, juga dilakukan oleh responden kedua dan ketiga (tapi kedua responden ini lebih mengembangkan metode lainnya), selain menggunakan metode kuliah konvensional (ceramah dan tanya jawab) juga mengembangkan metode 'riset sosial-keagamaan' sederhana kemudian dikupas dengan metode 'studi ushul' dan 'lintas mazhab'.

Maksudnya, masalah sosial-keagamaan digali dari kasus nyata di lapangan, kemudian penilaiannya dikembalikan kepada dasar-dasar Islam dan dikupas secara lintas mazhab tanpa fanatik terhadap salah satu mazhab atau merendahkan mazhab lainnya. Kasus yang dibahas di kelas: pembakaran kampung warga tarekat Tijaniyah di wilayah selatan Kabupaten Sukabumi Jawa Barat,17 dan pembakaran rumah-rumah warga Ahmadiyah di Cikeusik Pandeglang Banten.18 Adapun kasus paling parah di tahun 2011 terjadi pembakaran rumah-rumah, rumah tokoh, masjid, dan pesantren, serta pengusiran minoritas warg Syi’ah di Sampang Madura.19

Kajian kasus di kelas hanya menyoroti sisi agama, tidak menyoroti sisi keamanan. Persoalan utamanya, apakah ajaran Islam membenarkan tindakan kekerasan terhadap mazhab Islam minoritas? Dengan metode/pendekatan 'studi ushul' masalah ini

17 Eramuslim.com, Aliran Sesat ... diakses 23 Agustus 2012.

18 Tempo.co., Kronologi Penyerangan ... diakses 6 Februari 2011.

19 Fianto, J.A. "Refresentasi Peristiwa Kerusuhan ... (2015): 162-172. 
dikupas dengan uji Rukun Iman dan Rukun Islam. Bukan urutannya melainkan keenam Rukun Iman dan kelima Rukun Islam itu apakah dipercaya oleh mazhab-mazhab minoritas tersebut. Apakah warga tarekat Tijaniyah, Syi`ah, dan Ahmadiyah beriman kepada Allah, Malaikat-malaikat-Nya, Kitab-kitab-Nya, Rasul-rasul-Nya, Hari Akhir, dan kepada qodho dan qadar? Apakah ketiga warga minoritas itu mewajibkan mengucapkan dua kalimat syahadat, shalat zhuhur-asharmaghrib-isya dan shubuh, berpuasa di bulan ramadhan, membayar zakat, dan hajji ke baitullah? Jika ya maka mazhab mereka tidak boleh dinilai menyimpang, terlebih-lebih dituduh sesat dan kafir.

Kalau pun ada perbedaan, setiap mazhab pun ada saja perbedaannya. Dengan metode 'lintas mazhab' lebih dimaksudnya untuk menyadarkan mahasiswa bahwa: (1) di dunia Islam itu terdapat mazhab-mazhab Islam, (2) ajaran mazhab sebenarnya lebih banyak persamaannya - terutama menyangkut Rukun Iman dan Rukun Islam, sehingga persamaannya jauh lebih besar, (3) masing-masing mazhab itu memiliki perbedaanperbedaan di luar Rukun Iman dan Rukun Islam. Contoh, Rukun Iman Syi ah adalah tauhid (beriman kepada Keesaan Allah), ‘adalah (beriman kepada Keadilan Allah), nubuwah (beriman kepada Nabi-nabi), imamah (beriman kepada imam-imam pasca Nabi), dan ma`ad (beriman kepada hari akhir). Tapi mereka beriman pula kepada Rukun Iman yang enam. Ahmadiyah mempercayai adanya Nabi setelah Nabi Muhammad saw. Tapi mereka memandang: (1) Nabi Muhammad saw. adalah Nabi Besar, Nabi rahmatan li al-'alamin. Sampai di sini Ahmadiyah sama dengan Islam pada umumnya; dan (2) Mirza Gulam Ahmad adalah Nabi pelanjut Nabi Muhammad saw., dan mungkin akan ada lagi nabi-nabi lainnya pelanjut Mirza Gulam Ahmad. Tapi Nabi pelanjut Nabi Muhammad itu mengikuti ajaran Islamnya Nabi Muhammad, tidak membuat ajaran baru. Nama agamanya Islam, Rukun Iman dan Rukun Islamnya sama. Adapun pembeda 
yang utama adalah kepercayaan akan adanya Nabi setelah Nabi Muhammad saw. Tapi keberadaan Nabi setelah Nabi Muhammad di kalangan mereka sebenarnya mirip dengan kepercayaan kaum tarekat terhadap guru mursyid atau kaum Syi ah terhadap Imam ma`shum yang memiliki fungsi sebagai pelestari ajaran Nabi Muhammad saw., sama sekali tidak mengubah Rukun Imannya. Dengan metode ini lebih ditekankan bahwa perbedaan yang ada pada mazhab-mazhab lebih bersifat ijtihadiyah karenanya memiliki kemungkinan benar dan salah. Tapi di luar Tuhan dan Nabi tidak ada seorang pun yang dapat mengklaim hasil ijtihad mazhabnya benar, sedangkan hasil ijtihad mazhab lain salah.

Responden kedua, selain menggunakan metode yang diimplementasikan oleh responden pertama, juga mengimplementasikan metode 'studi agama-agama' (bukan perbandingan agama). Metode ini mengadopsi metode 'tipologi agama'-nya Ali Syari’ati. Metode tipologi agama merupakan sebuah metode yang dipakai secara luas di Eropa untuk mengetahui dan memahami manusia. Dalam konteks ini, Ali Syari ati mengembangkan metode khusus untuk mengkaji agama, yang bahkan dapat dipakai untuk mengkaji semua agama. Ali Syari’ati mengilustrasikan dengan pribadi manusia. Dilihat dari tipologinya, manusia dapat dikategorikan sebagai berkarakter sanguin, kolerik, melankolis, plegmatik. Demikian juga agama dapat dikategorikan sebagai bertipe Islam, Kristen, Katolik, Hindu, Buddha, Konghucu, dan lainnya. Metode 'tipologi agama' tidak menilai suatu agama tertentu lebih baik dibandingkan agama lainnya melainkan mengungkapkan secara deskripkriptif masing-masing tipe agama dengan segala ciricirinya. Metode 'tipologi agama' memiliki dua ciri penting, yaitu: pertama. mengidentifikasi lima aspek agama (Tuhan, Nabi, Kitab Suci, situasi kedatangan Nabi, dan Individu-individu pilihan yang dilahirkan oleh setiap agama); dan kedua, mendeskripsikan kelima aspek agama tersebut dengan aspek yang sama dalam 
agama lain.20 Tapi metode 'studi agama-agama' bukan hanya mendeskripsikan melainkan juga menilai terhadap aspek agama di luar Islam. Tujuan utamanya, agar mahasiswa kokoh dengan agamanya sendiri (agama Islam) juga memahami dan toleran terhadap agama lain.

Model pembelajaran 'studi agama-agama' diimplementasikan dengan bantuan tabel/format pembelajaran, seperti contoh berikut.

Tabel 1: Format Pembelajaran Metode 'Studi Agama-agama' Islam dan Kristen

\begin{tabular}{|c|c|c|c|c|}
\hline No. & $\begin{array}{c}\text { Aspek } \\
\text { Ajaran }\end{array}$ & Kristen* & Islam & Penilaian \\
\hline 1. & $\begin{array}{l}\text { Bagaima } \\
\text { na } \\
\text { konsep } \\
\text { Tuhan? }\end{array}$ & $\begin{array}{l}\text { Maha Esa dan } \\
\text { Maha Kuasa, } \\
\text { memiliki lebih dari } \\
99 \text { Nama (Sifat) } \\
\text { Pencipta dan } \\
\text { penguasa alam } \\
\text { semesta } \\
\text { Maha Pengasih dan } \\
\text { Maha Penyayang }\end{array}$ & $\begin{array}{l}\text { Maha Esa dan } \\
\text { Maha Kuasa, } \\
\text { memiliki 99 Nama } \\
\text { (Sifat) } \\
\text { Pencipta dan } \\
\text { penguasa alam } \\
\text { semesta } \\
\text { Maha Pengasih dan } \\
\text { Maha Penyayang }\end{array}$ & $\begin{array}{l}\text { Sifat-sifat } \\
\text { Tuhan } \\
\text { perspektif } \\
\text { Kristen sama } \\
\text { dengan } \\
\text { perspektif } \\
\text { Islam }\end{array}$ \\
\hline 2. & $\begin{array}{l}\text { Bagaima } \\
\text { na } \\
\text { konsep } \\
\text { trinitas? }\end{array}$ & $\begin{array}{l}\text { Tritunggal atau } \\
\text { Trinitas adalah } \\
\text { doktrin Iman } \\
\text { Kristen yang } \\
\text { mengakui Satu } \\
\text { Allah Yang Esa, } \\
\text { namun hadir dalam } \\
\text { Tiga Pribadi. Allah } \\
\text { Bapa, Putra, dan } \\
\text { Roh Kudus, di } \\
\text { mana ketiganya } \\
\text { adalah sama } \\
\text { esensinya, sama } \\
\text { kedudukannya, } \\
\text { sama kuasanya, } \\
\text { dan sama }\end{array}$ & $\begin{array}{l}\text { Dalam QS 4/al- } \\
\text { Nisa ayat 171 } \\
\text { dikupas tentang } \\
\text { trinitas sbb: } \\
\text { Wahai Ahli Kitab, } \\
\text { janganlah kamu } \\
\text { melampaui batas } \\
\text { dalam agamamu, } \\
\text { dan janganlah } \\
\text { kamu mengatakan } \\
\text { terhadap Allah } \\
\text { kecuali yang benar. } \\
\text { Sesungguhnya Al- } \\
\text { Masih, Isa putera } \\
\text { Maryam itu, adalah } \\
\text { utusan Allah dan }\end{array}$ & $\begin{array}{l}\text { Islam tidak } \\
\text { mengenal } \\
\text { konsep } \\
\text { Trinitas. } \\
\text { Konsep Maha } \\
\text { Esa dalam } \\
\text { Islam tidak } \\
\text { bisa dipilah- } \\
\text { pilah. Tuhan } \\
\text { ya Tuhan, } \\
\text { Nabi Isa ya } \\
\text { Utusan Tuhan } \\
\text { (bukan } \\
\text { Tuhan), dan } \\
\text { Roh Kudus ya } \\
\text { Roh Kudus }\end{array}$ \\
\hline
\end{tabular}

20 Dabla, B.A., Ali Syari ati dan Metodologi Pemahaman Islam," terj. Bambang Gunawan. Jurnal Al-Hikmah Yayasan Muthahhari Bandung, Vol. 199 No. 4 (Rabi al-Tsani-Sya`ban 1412/Nopember 1991-Februari 1992). 


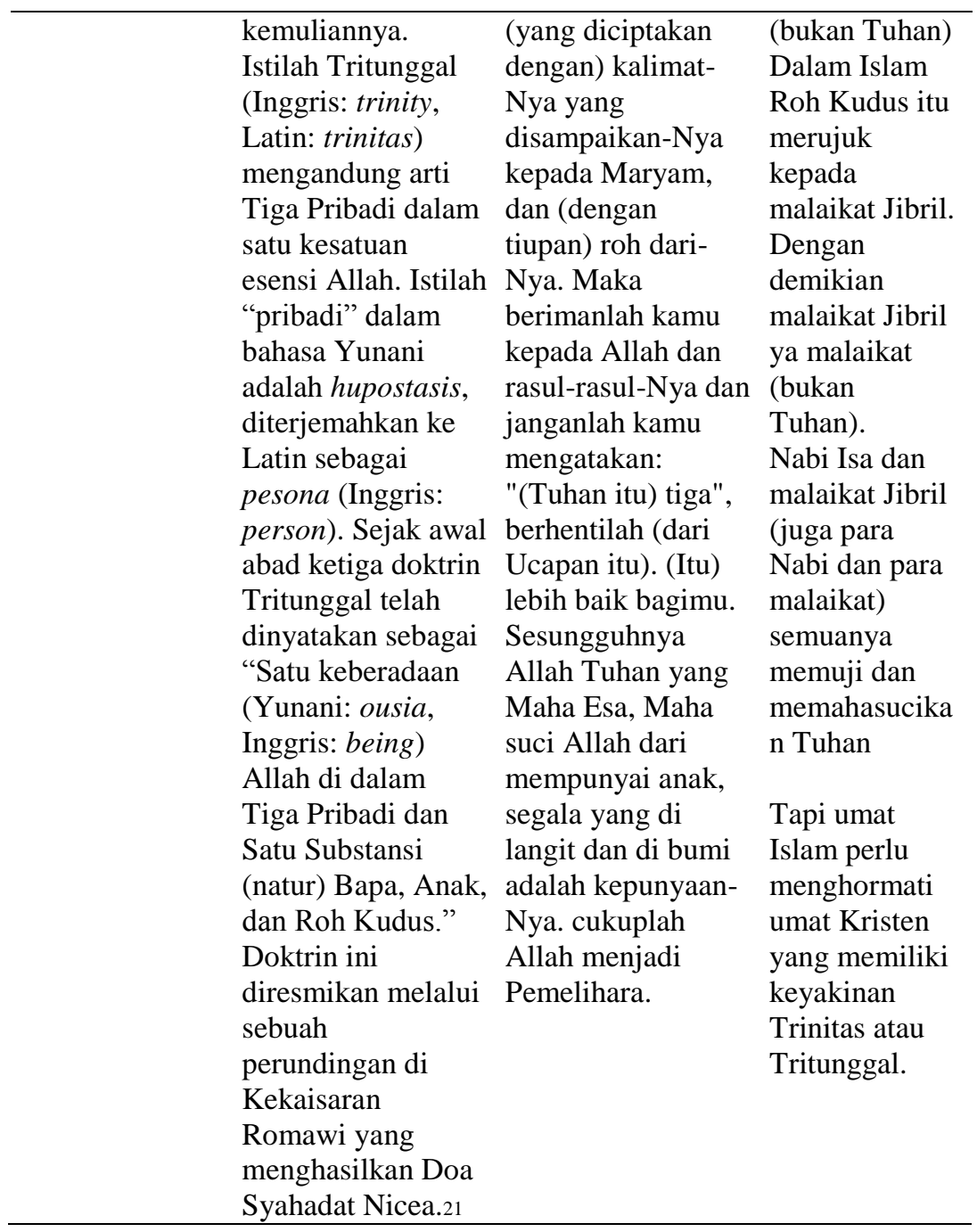

Setelah mendeskripsikan komponen-komponen agama perspektif Kristen dan Islam serta memberikan penilaian terhadap keyakinan agama Kristen, ternyata para mahasiswa menunjukkan hal-hal berikut:

1. Memahami pokok-pokok ajaran agama Kristen dari sumber Kristen;

21 Wikipedia.org., Tritunggal, (http://www.id.wikipedia.org) (online) diakses 22 Februari 2018. 
2. Memahami pokok-pokok ajaran Islam secara lebih mendalam dan luas;

3. Memiliki keyakinan religius Islam yang lebih kokoh;

4. Menghormati keyakinan penganut agama Kristen yang memiliki keyakinan berbeda.

Responden ketiga, selain menggunakan metode yang diimplementasikan oleh responden pertama, juga mengimplementasikan metode 'tipologi mazhab' (bukan perbandingan mazhab). Metode ini diilhami dari metode 'tipologi agama'nya Ali Syari'ati. Denggan metode ini diharapkan mahasiswa lebih memahami mazhab dan keyakinan religiusnya sendiri serta memahami pokok-pokok ajaran mazhab dan keyakinan religius mazhab lain serta bersikap toleran terhadap ajaran dan penganut mazhab lain yang berbeda. Metode ini memiliki dua ciri penting: pertama. mengidentifikasi komponenkomponen mazhab yang utama; dan kedua, membandingkan komponen-komponen mazhab ini dengan komponen-komponen yang sama dalam mazhab lain. Makna mazhab dalam metode 'tipologi mazhab' bukanlah mazhab teoritis dan klasik semacam mazhab Hanafi-Maliki-Syafi i dan Hanbali dalam bidang fiqih, atau mazhab Asy`ariyah-Maturidiyah dan Mu’tazilah dalam bidang teologi. Makna mazhab dalam metode 'tipologi mazhab' adalah mazhab-mazhab nyata yang ada di masyarakat dengan ciri-ciri: ada ajarannya, ada jamaahnya, ada ulamanya, dan ada lembaga pendidikannya. Misalnya Sunni-Syi`ah-Wahhabi dan Ahmadiyah di Dunia Islam atau NU-Muhammadiyah dan Persis di Indonesia.

Model pembelajaran metode 'tipologi mazhab' diimplementasikan dengan bantuan tabel/format pembelajaran, seperti contoh berikut. 
Tabel 2: Format Pembelajaran Metode 'Tipologi Mazhab'Sunni-Syi ah

\begin{tabular}{|c|c|c|c|}
\hline No. & $\begin{array}{c}\text { Aspek } \\
\text { Mazhab }\end{array}$ & Syi’ah & Sunni \\
\hline 1. & Imamah & $\begin{array}{l}\text { Agama merupakan } \\
\text { otoritas Tuhan yang } \\
\text { hanya dapat diemban } \\
\text { oleh manusia-manusia } \\
\text { ma`shum (suci, } \\
\text { terbebas dari dosa dan } \\
\text { salah). Nabi dengan } \\
\text { jelas menunjuk Ali ibn } \\
\text { Abi Thalib dan ahlul } \\
\text { bait-nya sebagai } \\
\text { pelanjut kepemimpinan } \\
\text { Nabi, karena mereka } \\
\text { manusia-manusia } \\
\text { ma`shum.Perspektif } \\
\text { Syiah Itsna } \\
\text { Asy`ariyah ke-12 } \\
\text { Imam pasca Nabi itu: } \\
\text { Ali ibn Abi Talib, } \\
\text { Hasan ibn Ali, Husain } \\
\text { ibn Ali, Ali Zainal } \\
\text { Abidin, Muhammad al- } \\
\text { Baqir, Ja`far al-Shadiq, } \\
\text { Musa al-Kazhim, Ali } \\
\text { al-Ridha, Muhammad } \\
\text { al-Jawad, Ali al-Hadi, } \\
\text { Hasan al-Askari, dan } \\
\text { Muhammad al-Mahdi. }\end{array}$ & 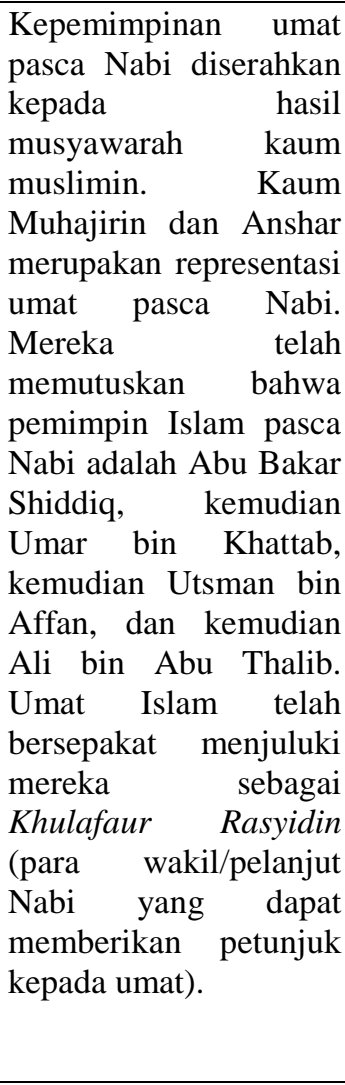 \\
\hline 2. & Taqiyah & $\begin{array}{lr}\text { Taqiyah } & \text { didasarkan } \\
\text { pada QS } & \text { 16/al-Nahl } \\
\text { ayat 106: "Barang siapa } \\
\text { yang kafir kepada Allah } \\
\text { sesudah dia beriman } \\
\text { (dia mendapat } \\
\text { kemurkaan Allah), } \\
\text { kecuali orang yang } \\
\text { dipaksa kafir padahal } \\
\text { hatinya tetap tenang } \\
\text { dalam beriman (dia } \\
\text { tidak berdosa), akan } \\
\text { tetapi orang yang } \\
\text { melapangkan dadanya } \\
\text { untuk kekafiran, maka }\end{array}$ & $\begin{array}{l}\text { QS 16/al-Nahl ayat 106: } \\
\text { "Barang siapa yang } \\
\text { kafir kepada Allah } \\
\text { sesudah dia beriman } \\
\text { (dia mendapat } \\
\text { kemurkaan Allah), } \\
\text { kecuali orang yang } \\
\text { dipaksa kafir padahal } \\
\text { hatinya tetap tenang } \\
\text { dalam beriman (dia } \\
\text { tidak berdosa), akan } \\
\text { tetapi orang yang } \\
\text { melapangkan dadanya } \\
\text { untuk kekafiran, maka } \\
\text { kemurkan }\end{array}$ \\
\hline
\end{tabular}




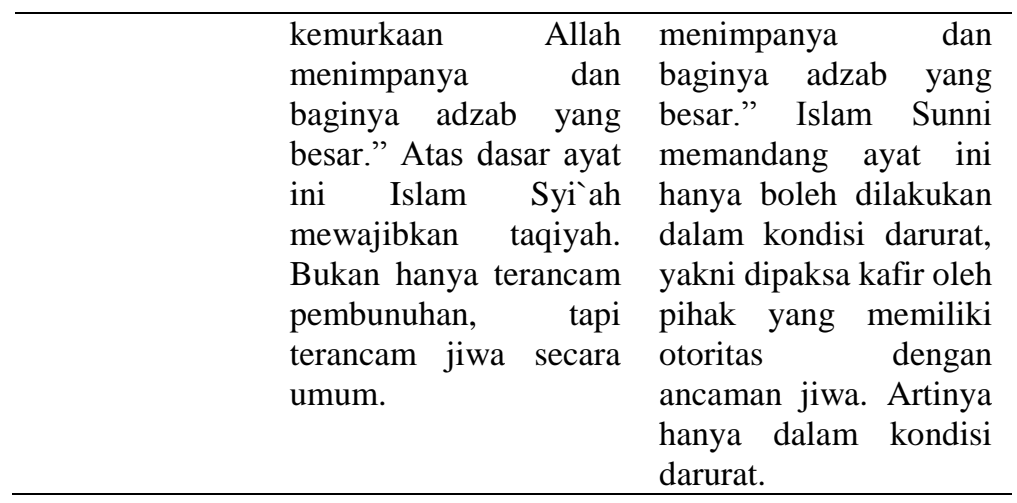

Dari uraian diatas dapat dipahami bahwa model perkuliahan PAI yang damai dan moderat menggunakan model materi PAI yang substantif dan metode perkuliahan dengan metode 'studi ushul', 'tipologi mazhab', 'tipologi agama' yang dialogisargumentatif para mahasiswa dapat memahami ajaran utama agama-agama dan mazhab-mazhab secara lebih luas dan mendalam. Para mahasiswa pun lebih banyak yang bersikap toleran terhadap agama, mazhab, serta penganut agama dan mazhab yang berbeda.

Temuan penelitian, model perkuliahan yang memadukan pemilihan substansi materi PAI yang inklusif dan metode perkuliahan yang dialogis-argumentatif ternyata dapat meningkatkan pemahaman dan toleransi mahasiswa terhadap agama-agama dan mazhab-mazhab seagama yang berbeda. Temuan penelitian ini sejalan dan memperkuat temuan-temuan penelitian sebelumnya. Firdaus \& Rahmat menemukan, model pembelajaran 'studi agama-agama' terbukti efektif dalam meningkatkan pemahaman dan toleransi beragama pada mahasiswa UPI.22 Bahkan di level sekolah menengah pun metode 'studi agama-agama' lebih memperkokoh keyakinannya terhadap Islam dan dapat meningkatkan toleransinya terhadap agama

22 Firdaus, E. \& Rahmat, M., 2017, Studi Model Studi Agama-agama dalam Perkuliahan PAI untuk Meningkatkan Pemahaman dan Toleransi Beragama Mahasiswa, Penelitian Kompetitif pada LPPM UPI Bandung. 
lain.23 Syahbudin \& Hanafi menemukan, model desain pembelajaran berbasis multikultural di SMA Kartini Kabupaten Rokan Hilir Riau berpengaruh terhadap keberhasilan pendidikan multikultural dan mengurangi konflik di kalangan siswa.24 Kemudian Rahmat menemukan, metode ‘tipologi mazhab' Islam Sufi -dapat meningkatkan pemahaman dan keberterimaan mahasiswa terhadap Islam Sufi dan tarekat.25 Sebelumnya, Rahmat \& Fahrudin melalui penelitian kuasi eksperimen menemukan, model perkuliahan 'studi ushul' dan 'lintas mazhab' terbukti dapat meningkatkan pemahaman dan toleransi mahasiswa terhadap mazhab berbeda. 26

Penelitian ini bukan hanya menonjolkan metode perkuliahan (yang dialogis-argumentatif) tapi juga menonjolkan pemilihan substansi materi yang inklusif. Tema-tema perkuliahan dipilih yang diduga dapat meningkatkan keberagamaan yang damai, moderat, dan toleran. Dalam penelitian ini substansi materi PAI yang dapat meningkatkan pemahaman dan toleransi beragama pada mahasiswa ada 7, yakni: (1) Makna beragama Islam adalah tunduk- patuh secara mutlak kepada Allah dan Rasul-Nya; (2) Misi (tujuan utama) agama Islam adalah 'menyempurnakan'

23 Firdaus, E. \& Rahmat, M., "Learning Model of Religious Tolerance (A Study of The Increase of Life Cohesion for Students)," The 1st UPI International Conference on Islamic Education. Islamic Education Faces Global Challenges (19 Oktober 2016): 151-155

24 Syahbudin, Z. \& Hanafi, M., "The Model of Learning Design Based on Islamic Multicultural Education to Prevent Conflicts of Behavior," Jurnal Pendidikan Agama Islam UIN Sunan Gunung Djati Bandung, Vol. 3 No. 2 (2017): 155-168.

25 Rahmat, M., "Studi Model Pembelajaran "Tipologi Mazhab" dalam Perkuliahan Seminar PAI untuk Meningkatkan Pemahaman dan Toleransi se Agama pada Mahasiswa UPI," The 1st UPI International Conference on Islamic Education. Islamic Education Faces Global Challenges (19 Oktober 2016): 215-221.

26 Rahmat, M., \& Fahrudin, 2008, Model Pembelajaran Studi Ushul dan Lintas Mazhab dalam Perkuliahan Seminar PAI untuk Meningkatkan Pemahaman dan Toleransi Mahasiswa Terhadap Sesama Muslim Beda Mazhab. Penelitian Kompetitif pada LPPM UPI Bandung. 
akhlak mulia; (3) Meneladani kesempurnaan keimanan, ketakwaan, peribadatan, akhlak mulia, dan ilmu Rasulullah (tentu semampu masing-masing); (4) Keragaman mazhab dan keyakinan religius dalam Islam sebuah keniscayaan; (5) Makna iman bukan hanya ditujukan kepada orang Islam dan makna kafir bukan ditujukan kepada orang-orang yang beragama non Islam; (6) Karakter Ahli Kitab dalam Al-Quran ada yang jujur dan ada yang tidak jujur, ada yang rendah hati dan ada yang sombong, ada yang beriman dan ada yang kafir. Jadi tidak boleh divonis kafir; dan (7) Kriteria Islam 'menyimpang' adalah orang Islam yang jelas-jelas menyimpang dari Rukun Iman dan Rukun Islam, tapi tetap tidak boleh divonis kafir, karena hak prerogatif memberikan vonis kafir kepada seseorang hanyalah Allah dan Rasul-Nya.

\section{Simpulan}

Pendidikan Agama Islam yang damai, moderat, dan toleran dipengaruhi oleh faktor keterbukaan dosen, substansi materi yang inklusif, dan metode perkuliahan yang dialogis-argumentatif. Sikap keberagamaan terbuka dosen merupakan faktor paling berpengaruh dalam perkuliahan PAI yang damai, moderat, dan toleran. Model perkuliahan yang memadukan pemilihan substansi materi PAI yang inklusif dan metode perkuliahan yang dialogis-argumentatif ternyata dapat meningkatkan pemahaman dan toleransi mahasiswa terhadap agama-agama dan mazhab-mazhab seagama yang berbeda. Metode-metode perkuliahan yang dialogis-argumentatif hasil penelitian ini adalah: (1) pendekatan 'riset sosial-keagamaan' sederhana dikaji dengan 'studi ushul' dan 'lintas mazhab', (2) pendekatan 'studi agama-agama' disertai pandangan kritis-terbuka terhadap ajaran pokok agama lain, dan (3) metode 'tipologi mazhab' dengan sumber/referensi dari mazhab yang dikaji. 


\section{Daftar Pustaka}

Bbc.com., Ajaran Syiah, menurut MUI, tidak dilarang di Indonesia, (http://www.bbc.com/indonesia) (online) diakses 15 Oktober 2015.

Clark, W.H., 1968, The Psychology of Religion: An Introduction to Religious Experience and Behavior, The MacMillan Company, New York.

Dabla, B.A., "Dr. Ali Syari`ati dan Metodologi Pemahaman Islam," terj. Bambang Gunawan. Jurnal Al-Hikmah Yayasan Muthahhari Bandung, Vol. 199 No. 4 (Rabi`alTsani-Sya`ban 1412/Nopember 1991-Februari 1992).

Ditjen Pendidikan Islam Kemenag, Nominator Penerima Apresiasi Pendidikan Islam untuk Guru dan Dosen Pendidikan Agama Islam 2017, SK Ditjen Pendidikan Islam Kemenag RI No. 6921 Tahun 2017, 20 November 2017.

Eramuslim.com, Aliran Sesat Pemicu Konflik di Sukabumi? (http://www.eramuslim.com.) (online) diakses 23 Agustus 2012.

Fianto, J.A. "Refresentasi Peristiwa Kerusuhan Sunni Syiah di Sampang Madura dalam Foto-foto di Majalah Tempo Edisi 24 Agustus 2011-11 Agustus 2013," Jurnal Commonline Departemen Komunikasi, Vol. 4 No. 1 (2015)

Firdaus, E. \& Rahmat, M., 2015, Studi Model Pembinaan Toleransi Beragama dalam Pembelajaran PAI untuk Meningkatkan Kerukunan Hidup Beragama Bagi Siswa SMA di Kota-kota Besar dan Multi Etnik. Penelitian Unggulan Perguruan Tinggi Dikti pada LPPM UPI Bandung.

Firdaus, E. \& Rahmat, M., "Learning Model of Religious Tolerance (A Study of The Increase of Life Cohesion for Students)," The 1st UPI International Conference on Islamic Education. Islamic Education Faces Global Challenges (19 Oktober 2016)

Firdaus, E. \& Rahmat, M., 2017, Studi Model Studi Agamaagama dalam Perkuliahan PAI untuk Meningkatkan Pemahaman dan Toleransi Beragama Mahasiswa, Penelitian Kompetitif pada LPPM UPI Bandung. 
Fokustoday.com., Muhammadiyah: Tidak ada fatwa sesat buat Syi'ah, (https://www.fokustoday.com.) (online) diakses 13 Oktober $/ 2017$.

Ismail, R., "Konsep Toleransi dalam Psikologi Agama (Tinjauan Kematangan Beragama)," Religi - Jurnal Studi AgamaAgama, Vol. 8 No. 1 (Januari 2012)

James, W., 1958, The Varieties of Religious Experience: A Study in Human Nature, Modern Library, New York.

Mujani, Kecenderungan Radikalisme Agama Akhir-akhir Ini, (http://www.islamlib.com.) (online) diakses 20 Maret 2006.

Rahmat, M., "Corak Berpikir Keagamaan Mahasiswa (Eksklusif, Inklusif, dan Liberal)," Taklim - Jurnal Pendidikan Agama Islam, Vol. 10 No. 1 (Maret 2012)

Rahmat, M., "Studi Model Pembelajaran "Tipologi Mazhab" dalam Perkuliahan Seminar PAI untuk Meningkatkan Pemahaman dan Toleransi se Agama pada Mahasiswa UPI," The 1st UPI International Conference on Islamic Education. Islamic Education Faces Global Challenges (19 Oktober 2016)

Rahmat, M., \& Fahrudin, 2008, Model Pembelajaran Studi Ushul dan Lintas Mazhab dalam Perkuliahan Seminar PAI untuk Meningkatkan Pemahaman dan Toleransi Mahasiswa Terhadap Sesama Muslim Beda Mazhab. Penelitian Kompetitif pada LPPM UPI Bandung.

Syafìi, Radikalisme Beragama, (http://www..islamlib.com.) (online) diakses 20 Maret 2006.

Syahbudin, Z. \& Hanafi, M., "The Model of Learning Design Based on Islamic Multicultural Education to Prevent Conflicts of Behavior," Jurnal Pendidikan Agama Islam UIN Sunan Gunung Djati Bandung, Vol. 3 No. 2 (2017) Syahidin \& Rahmat, M., 2009, Corak Berpikir Keagamaan Mahasiswa di Jawa Barat: Dari Corak Berpikir Keagamaan yang Eksklusif, Inklusif, hingga Liberal. Penelitian Kompetitif Dikti pada LPPM UPI Bandung.

Tempo.co., Kronologi Penyerangan Jamaah Ahmadiyah di Cikeusik. (http://www.m.tempo.co.) (online) diakses 6 Februari 2011. 
Tempo.co., Said Aqil: Syiah Tidak Sesat. (https://www.nasional.tempo.co.) (online) diakses 27 Januari 2012.

Tempo.co., Muhammadiyah dan NU Tolak MUI Fatwakan Sesat Syi ah, (https://www.nasional.tempo.co.) (online) diakses 20 Desember 2013.

Thalib, al-Ustad Ja'far Umar, Toleransi Beragama, (http://www.indonesiaindonesia.com.) (online) diakses 15 Oktober 2014.

Wahab, 2015, Kumpulan Hadits Sesuai Abjad. E-Book (http://www.ahabiy.blogspot.com.).

Wikipedia.org., Tritunggal, (http://www.id.wikipedia.org) (online) diakses 22 Februari 2018. 